\title{
JUSTIÇA FEDERAL NO BRASIL - UM CAMINHO REPUBLICANO DESDE 1890
}

\author{
. Marcelo Guerra Martins*
}

\begin{abstract}
Resumo:
No País o nascimentu da Justiça Federal coincide com a instauração da República; a partir daí o autor apresenta considerações acerca das circunstâncias e peculiaridades desde o nascimento, da Justiça Federal, de 1980.

Palavras-chave: Justiça Federal. Justiça Imperial. Principio Federativo. República.

Abstract:

In Brazil, the rise of Federal Courts coincides with the implementation of Republic; the authors analyses the circumstances and peculiarities in the creation of Brazilian Federal Courts.

Keywords: Brazilian Federal Courts. Brazilian Imperial Courts. Federal Principle. Rcpublic.
\end{abstract}

1. Introdução

O nascimento da Justiça Federal no Brasil coincide com a instauração da República. Pretende-se aqui tecer algumas considerações acerca das circunstâncias e peculiaridades de seu nascimento (em 1890), extinção (em 1937) e renascimento (em 1946 em Segunda Instância e 1967 em Primeira Instância), priorizando e identificando a defesa dos princípios republicanos e federativos.

Adverte-se, desde logo. não se tratar de estudo histórico exaustivo. minucioso ou mesmo de profundidade complexa. É que, entende-se ser de melhor proveito ligar a narrativa mais à importância do novo modelo judicial instalado, cm termos de novos horizontes na busca da concretude da independência, guarda dos princípios e normas constitucionais, do que simplesmente inventariar eventos.

Trata-se, untão. de manifestar impressões comparativas acerca dos acontecimentos históricos, ligando-os, em certa medida, aos caminhos seguidos pela Justiça Federal brasileira até a atualidade.

Em Ihana verdade, scm embargo de exceções pontuais, fato corrente é que o desconhecimento da história induz sua repetição, tantas vezes implicando retrocesso de

Mestre em Direito Civil pela Faculdade de Direito da Universidade de São Paulo e Juiz. Federal em São Paulo. 
avanços duramente conquistados, prejuizo do coletivo e homenagem a abusos desmedidos. É o que não se pode nem se deve permitir.

2. A justiça imperial

No período imperial, constituindo-se o Brasil em Estado centralizado, soaria absurda a idéia de uma Justiça vocacionada apenas às causas do Poder Central. Com efeito, recordemos que à época não havia Estados, apenas Províncias sob alto grau de dependência, sendo inclusive seus respectivos presidentes, nos moldes do art. 165 da Constituição Imperial de 1824 , 'nomeados c removidos pelo imperador.

A Justiça Imperial compunha-se tão-somente de juizus de Direito e jurados (em Primeira Instância); Relações (equivalentes aos atuais Tribunais de Segunda Instância) e do Supremo Tribunal de Justiça (arts. 15।, 152, I62 e 163 da $\mathrm{Cl}^{2}$ ).

O contexto era de inegável centralização, atingindo inclusive o Poder Judiciário. à época denominado Poder Judicial (Título $6^{\circ}$ da CI), ressaltando-se que ao Poder Moderador, ' exercido exclusivamente pelo Imperador (art. 101 da CI), era conferido, dentre outras faculdades, reformar sentenças. "Perdoando, e moderando as penas impostas e os Reos comndenados por Sentença" (inciso VIII do art. $101 \mathrm{da}$ CI).

Ora, é intuitivo constatar que a garantia constitucional de independência conferida à Magistratura (art. 15] da ('I) certamente poderia sc aquebrantar frente a eventuais injunções do Poder Central, notadamente porque a Carta de 1824 não previa a inamovibilidade dos juizes, atentando-se às dimensões continentais do Brasil e às notórias dificuldades de locomoção e comunicação então existentes.

A redação do art. 153 da $\mathrm{CI}$ não deixava dúvida a respeito ao estabelecer que: "Os Juizes de Direito serão perpetuos, o que todavia se não entende, que não possam ser mudados de uns para outros Lugares pelo tempo, e maneira, que a Lei determinar"

A redação era: "Arl. 165. Haverá em cada Provincia um Presidente. nomeado pelo Imperador. que o poderá remover. quando entender, que assim convem ao bom serviço do Esıado"

$\mathrm{Cl}$ - abruviação de Constituição Imperial.

Segundo Paulo Bonavides Paes de Andrade: "Em suma, o Poder Moderador. qual constava da Constituiçào; se opunha tanto à doutrina de Montesquieu, da separação de poderes, como à de Constant, que era a doutrina do poder neutro ou poder judiciário dos demais poderes. O Poder Moderador da Carta do Império é literalmente a constitucionalização do absolutismo, se isto fora possivel. Nesse ponto. Tobias Barreto tinha toda razão em esconjurá-lo. (...) Atribuiçōes de importância tão fundamental para o direito e a liberdade. para a vida e o funcionamento das instituiçōes eram conferidas a um Imperador cuja pessoa a Constituição fazia inviolável e sagrada declarando ao mesmo tempo que não estava cle sujeito a responsabilidade alguma (art. 99)". (História constitucional do Brasil. 3. ed. Rio de Janeiro: Editora Paz e Terra. 1991. p. 90-97). 
É interessante notar que o Imperador poderia executar serviços de natureza correicional em face dos juízes, podendo: "suspende-los por queixas contra elles feitas, precedendo audiencia dos mesmos Juizes, informação necessaria, e ouvido o Conselho de Estado"

A perda do cargo dependia de sentença, silenciando-se a Carta sobre a necessidade de trânsito em julgado (art. 155).

Esta ambiência centralizadora, intervencionista e até mesmo autoritária, perdurou juridicamente até 1889 , quando nasce a República, estruturada sob a forma federativa.

3. República e o princípio federativo

Conforme é notório, em face de várias circunstâncias político-militares, que aqui não cabem serem contempladas, em 15 de novembro de 1889, pelo Decreto n. 1, proclamava-se no Brasil a República, na forma de Federação, nestes termos:

\section{Art. I" - Fica proclamada provisoriamente e decretada como a forma de governo da Nação brasileira a República Federativa. \\ Art. $2^{\circ}$ As Províncias do Brasil, reunidas pelo laço da Federação, ficam constituindo os Estados Unidos do Brasil.}

O Império passara à história.

Todavia, como é bem sabido, tal evento não implicou em miraculosa ou significativa alteração das condições materiais e sociais do Brasil, essencialmente agrário e com população predominantemente concentrada nas proximidades da faixa litorânea. A industrialização ainda estava bem distante.

O cenário era bem diverso do atual. Fm 1890, o Brasil contava com aproximadamente 17 milhões de habitantes, a maioria residindo e trabalhando na zona rural; a economia praticamente dependia apenas do desempenho da agricultura. ${ }^{4}$

A Federação resultou, de imediato, na transmutação das antigas Provincias em Estados-membros. Assim, deu-se a união de coletividades públicas autônomas sob a ótica político-constitucional. ${ }^{5}$ Não se trata de qualquer união, mas sim aquela tida por indissolúvel, pois é certo que:

em qualquer época da história humana encontram-se referências a alianças entre I:stados, reconhecendo-se que só

- Dados colhidos no site do IBGE.

SILVA, José A fonso da. Curso de direiro constitucional posilivo. 21. ed. São Paulo: Malheiros, 2002. p. 99 e seguintes. 
algumas cunstituiram federações, o que demonstra, desde logo, yue essa uniâu deve apresentar algumas peculiaridades importantes que a distinguem das demais. ${ }^{6}$

As entidades unidas $\mathrm{em}$ regime federativo (por exemplo, os Estadosmembros e. em certos casos, os Municipios'), são dotadas de autonomia, nos moldes das competências estabelecidas na respectiva Carta Federal, mas não detém soberania, ${ }^{8}$ esta afeta exclusivamente à pessoa da União.

O Fstado Federal, da maneira cumu se concebe hodiernamente, é fenômeno relativamente novo, data mais precisamente de 1787. quando us Estados Unidos da Amírica editam sua Constituição. ${ }^{10}$ Apenas para recordar, em 1776, treze colônias britânicas, de forma conjunta, sc declararam independentes, tornando-se Estados, em tese, soberanos. Lntretanto, cra de rigor debelar qualquer ameaça de retorno ao status quo ante. Então, com vistas à garantir a recém declarada indepundência, na Convenção de Filadélfia, em 1787, instalou-se a Federaçào (o que existia até então era apenas uma Confederação), passando a soberania exclusivamente à União. Os Estados, então, eram titulares de competências; não mais de soberania.

DALL.ARI, Dalmo de Abreu. Elementos de teoria geral do estado. 19. ed. Sào Paulo: Saraiva, 1995. p. 215 216. Na mesma obra. o autor elenca as características do Estado federal, à saber: a uniāo faz nascer um novo Estado e, concomitantemente. aqueles que aderiram à federação perdem a condição de Estados; a base jurídica do Estado é uma Constituição, não um tratado; só o Estado Federal tem soberania; as atribuições da Uniào e as das unidades federadas sào fixadas na Constiluiçào. por meio de distribuição de competẻncias. não existindo hierarquia na organização federal; a cada esfera de competência se atribui renda própria; o poder politico é compartilhado entre a Uniāo e as unidades federativas: os cidadãos do Lstado que adere à Fcderação adquirem a cidadania do Estado Federal e perdem a anterior" (p. 218-219).

7 Parcela significativa da doutrina considcra que os Municípios, após da Constituição de 1988, compōem a Federação. Assim: BASTOS, Celso Ribeiro. Curso de direito constilucional. 19. ed. São Paulo: Saraiva, 1998. p. 294; SILVA, José A fonso da. ob.cil., p. 100: IIRREIRA FILHO, Manoul Gonçalves. Curso de direilo constitucional. 26. ed. São Paulo: Saraiva. 1999. p. 68.

8 A soberania pode ser enfocada sob o àmbito interno e externo. Pelo primeiro, a sobcrania corresponde ao poder do Estado de cditar normas juridicas de cunho coercitivo. podendo tomar medidas no sentido de obrigar os súditos a cumprir esses preceitos. No âmbito extemo, significa que as ordens juridicas estabelecidas pelos diversos tstados soberanos são independentes entre si, sendo que nenhuma delas pode prevalecer sobre a de outro listado. Na lição de Enrique Ricardo Lewandowski. mesmo em vista do surgimunto de comunidades de paists (União Européia, Mercosul. etc., ), a soberania não se distancia de seu signiticado inicial " "Direito comunitário e soberania - algumas reflexões" in Direiro commirario e jurisdição supranacional (coord. Errịue Ricardo Lewandowski). São Paulo: Ed. Juarez de Oliviria, 2000, p. 179 e seg.

9 Preleciona José Afonso da Silva: "Houve muita discussão sobre a natureza juridica do Estado federal. mas, hoje, já está definido que o Estado federal, o todo, como pessoa reconhecida pelo Direito internacional. ć o único titular da soberania, considerada poder supremo consistente na capacidade de autodeterminação. Os Estados federados são titulares tào-só de autonomia. compreendida como governo próprio dentro do circulo de compelências traçadas pela (constituição Federal' (ob. cit., p. 100). Na mesma linha: FERREIRA FILHO, Manoel Gonçalves. ob. cit., p. 53.

10 DALLARI, Dalmo de $\wedge$ breu. ob. cit. p. 216 e seguintes. 
Em moldes constitucionais, o Brasil segue a estrutura federativa desde a Constituição de $1891\left(\right.$ art. $\left.1^{\circ}\right)$.

Nossa Federação, ¿́ verdade reconhecida, possui característica bem peculiar. que a distancia em certa medida daquela instituida nos Estados Unidos da América. Enquanto lá o fenômeno ocorrido foi o da aglutinação. isto é, as treze colônias se uniram. principalmente para garantir a independência. frente às ameaças do inimigo externo, aqui o Poder Central foi fragmentado e distribuído aos diversos recém-nascidos Estados, até então Províncias, passando estes a promoverem, às suas expensas, as necessidades de scus governos e administrações (art. $5^{\circ}$ da CR/81).

Então, a União somente prestaria socorro ao Estado em caso de calamidade pública, mediante solicitação (art. $5^{\circ}$ da CR/81).

Aliás, atentando-se às significativas diferenças e realidades (em vários aspectos) vividas pelas Províncias brasileiras de então, é bem certo, segundo expôs Carmén Lúcia Antunes da Rocha," que:

A federação brasileira não foi pensada brasileiramente. segundo as conveniências e necessidades brasileiras, quando foi implantada. Isto, que se tem denominado de federalismo simétrico, quer dizer. o Estado do Piaui tum a mesma normativização constitucional que o Estado de São Paulo, sendo realidades completamente diferentes, não é fruto de uma cogitação e conclusão sobrc o que seria mais conveniente para o Brasil.

Estas diferenças marcaram presença e se revelaram importantes nos caminhos seguidos pclas duas Federações, sendo certo que a brasileira não-tardou em sofrer, em poucas décadas, um desvirtuamento dos moldes iniciais, com o acentuado retorno da centralização. ${ }^{2}$

1 "O Supremo Tribunal Federal como árbitro dos conflitos federativos" in Anais do seminario o Supremo Tribunal Federal na história da Republica. s.ed., editado pela AJUFE, Brasília, 2002, p. 175.

12 Não se afirma, entretanto, tenha a Federação Norte-Americana restado absolutamente incólume à tendência centralizadora do inicio do Século XX. Segundo Dalmo de Abreu Dallari: "Observando os efeitos da atividade intervencionista reguladora exercida pelo Estado norte-americano, com a implantação do $\mathrm{New}$ Deal, diz Schwartz que, para o governo federal exercer, em âmbito nacional, a autoridade regulamentadora que as condições sociais requeriam, foi necessário abandonar o conceito de federalismo dualista. Assim como se substituiu a doutrina do laissez-faire por um intervencionismo inevitável em face das circunstâncias, assim também o federalismo dual precisou ser substituido por um federalismo cooperativo..." (O estado jederal. 5.ed. São Paulo: Editora Ática. 1986. p. 45). 


\section{O nascimento da Justiça Federal}

A proclamação da República, como não poderia deixar de ser, implicou na extinção dos títulos de nobreza e outras figuras afins. Passa a vigorar, ao menos legalmente, o principio da igualdade, sendo que toda autoridade encontra seu fundamento na lei e não em situações de índole pessoal ou mesmo na figura de alguém (por exemplo, o presidente da República). No âmbito judicial, a nova ideologia resta inequívoca com a edição do Decreto n. 25, de 30 de novembro de 1889: Assim, merece transcrição o seguinte:

Arl. $I^{\prime}(\ldots)$

(...)

$\S 2^{\prime \prime} \quad$ As carlas de sentença ¿' quaesquer outros actos $e$ documentos judiciários serão passados pelos juizes $e$ tribunaes competentes em seu nome e com autoridade que thes confere a lei. sem dependencia ou invocaçâo de poder estranho à magistratura judicial, salvo as requisições do necessurio auxilio da força publica ou de providencias administrativus que thes incumba fazer as autoridades, estabelecidas ou reconhecidas pelo Governo dos Estados Unidos do Brasil.

$\$ 3^{\circ}$ - Nos mandados, alvaras, editaes, precatorias, cartas de sentença e inais actos judiciários assignados pulo juiz. quer de rubrica, quer com o nome inteiro, os escrivães não porão uutro nome que o patronimico ou titular de que legalmente use o juiz e o do officio pelo qual conhece do feito, sem menção de quaisquer timulos, condecoraçōes ou dignidades que tenha, conforme determina a Ord. liv. $l^{\circ}$ tit. $79 . \$ 9^{\circ}$

Nesta conjuntura, pelo Decreto n. 848. de 11 de outubro de 1890. instituiuse a Justiça Federal. Conforme sua preclara exposição de motivos, de autoria do então Ministro da Justiça Campos Salles:

Não se trata de tribunaes ordinarios de justiça, com uma jurisdição pura e simplesmente restricta à applicação das leis nas multiplas relações do direito privado. A magistratura que agora se instala no paiz, graças ao regimen republicano, não é um intrumento cego ou mero interprete na execução dos actos do poder legislativo. Antes de applicar a lei cabe-lhe o direito de exame, podendo dar-lhe ou recusar-lhe sancção, si ella the parecer conforme ou contraria à lci orgânica. $O$ poder de interpretar as leis, disse o honssto e sabio juiz americano, envolve necessariamentc o direito de verificar si ellas são conformes ou nâo à constituição, e nuste último caso cabe-Ihe declarar que ellas são nullas e sem effeito. Por este engenhoso mechanismo consegue-se evitar que o 
legislador, reservando-se a faculdade da interpretação, venha a collocar-se na absurda situação de juiz em sua propria causa.

A alteração no papel do Poder Judiciário é evidente e notável. Esta noção é refletida, mais uma vez, na já mencionada Exposição de Motivos, cuja leitura é sempre proficua:

Ahi está posta a profunda diversidade de indole entre o poder judiciário, tal como se achava instituido no regimen decahido, e aquelle que agora se inaugura, calcado sobre os moldes democraticos do systema federal. De poder subordinado, qual era, transforma-se em poder soberano, apto na elevada esphera da sua autoridade para interpor a benefica influencia do seu criterio decisivo afim de manter o equilibrio, a regularidade e a propria independencia dos outros poderes, assegurando ao mesmo tempo o livre exercicio dos direitos do cidadão. É por isso que na grande União Americana com razão se considera o poder judiciário como a pedra angular do edificio federal e o único capaz de defender com efficacia a liberdade. a autonomia individual. Ao influxo da sua real soberania desfazem-se os erros legislativos e são entregues à austeridade da lei os crimes dos depositarios do poder executivo (ob. cit., p. 14).

A idéia principal do novo sistema não deixava dúvidas. Segundo bem prelecionou o grande Rui Barbosa: ${ }^{13}$

Na dualidade judiciaria da nossa organização constitucional, não póde haver senão duas idéias: a de uma justiça criada pelo Estado, e a de uma justiça ligada á União; a justiça local e a justiça federal.

A justiça local incumbe, como competencia que the é nativa, o dominio das relações civis de caracter commum; á justiça federal pertence privativamente o dominio dos factos e das relações de natureza politica, daquellas que entendem com o regimen constitucional, ou que tocam fundamentalmente ás instituições constitucionais.

Em respeito ao princípio da dualidade, cada Estado era detentor de autonomia para legislar acerca da respectiva organização judiciária e procedimentos, sendo o "processo federal" disciplinado no Título III do Decreto n. 848.

Dessa sorte, a Justiça Federal se instituiu em duas Instâncias (art. $1^{\circ}$ do Decreto n. 848).

1) Comentários a Constituição Federal brasileira. São Paulo: Saraiva, 1933. v. 4, p. 61-62. 
A Primeira Instância se compunha dos Juizes de Secção, vitalícios e inamoviveis (art. 13 do Decreto n. 848); Juízes Substitutos. inamovíveis, mas nomeados apenas por seis anos (art. 18 do Decreto n. 848) e Juízes ad hoc que atuavam somente pelo tempo que perdurasse a impossibilidade dos Substitutos. Todos eram de livre nomeação pelo Presidente da República.

Por fim, havia o júri federal, para os crimes sujeitos à jurisdição federal (art. 40 do Decreto n. 848).

Cada Estado representava uma "secção judicial" da Justiça Federal, que era composta por um Juiz de Secção e um Substituto (arts. 13 e 18 do Decreto n. 848).

Aos Juizes de Secção competia processar e julgar: causas fundadas na Constituição Federal ou em atos administrativos do Governo Federal; litígios entre um Fstado e habitantes de outros Estados ou do Distrito Federal; litígios entre habitantes de Fstados diferentes ou do Distrito Federal quando ocorresse diversidade nas respectivas legislações: demandas que interessavam ao fisco nacional; pleitos entre nações estrangeiras e cidadãos brasileiros ou domiciliados no Brasil; ações movidas por estrangeiros fundadas em tratados internacionais: questões de Direito Marítimo e de navegação em águas da União; e crimes políticos definidos no Código Penal de então (art. 15 do Decreto n. 848).

Bem diverso dos dias atuais, a Segunda Instância era constituida pelo Supremo Tribunal Federal, composto então por quinze juizes, também de livre nomeação pelo presidente da República, após aprovação pelo Senado (arts. $5^{\circ}$ e $9^{\circ}$, II, do Decreto $n$. 848).

O Supremo também era detentor de competência originária (art. $9^{\circ} 1$ do Decreto n. 848). Neste assunto, cabia-lhe processar e julgar o presidente da República, nos crimes comuns; os juízes de Secção, nos crimes de responsabilidade; os ministros diplomáticos, em ambos os casos: os pleitos entre a União e os Estados, ou destes entre si; os litigios entre nações estrangciras e a União ou os Estados; suspeição oposta a qualquer de seus membros; conflitos de jurisdiçăo entre juizes federais ou entre estes e os dos Estados.

Além da competência originária, competia-lhe, em grau de recurso, julgar: questões decididas pelos Juízes de Secção de valor superior a 2:000\$00: casos relativos à sucessão de estrangeiro quando não-regulamentadas em tratado; ações criminais julgadas por Juiz de Secção ou pelo Júri Federal; suspeições opostas aos Juizes de Secção (art. $9^{\circ}$, I] do Decreto n. 848).

Competia ao Supremo, ainda em grau de recurso, julgar as decisões definitivas proferidas por Tribunais e Juizes dos Estados quando se verificasse: 
contrariedade a tratado internacional, à lei ou ao exercício de qualquer autoridadu da União; que a decisão atacada conferira validade à lei ou ato estadual em conflito com lıi ou ato constitucional nu federal: conflito com preceito constitucional, federal ou de tratado internacional (parágrafo único do art. $4^{\circ}$ do Decreto n. 848).

Tambím competia à Fxcelsa Cortc a revisão du quaisquer processos criminais findos; a concessâo de haheas corpus em recurso voluntário, quando denegado por juiz federal ou por juiz ou Tribunal estadual; a apresıntação anual, ao presidente da República, de sua estatística processual (art. $9^{\circ}$ III do Decreto n. 848).

Os juízes do STF seriam julgados pelo Senado, nos crimes de responsabilidade (art. 10 do Decreto n. 848).

O saudoso ministro Fivandro Lins e Silva ${ }^{14}$ afirmou com sua costumeira propriedade:

$\dot{F}$ realmente admirável como os ministros dos primciros tempos assimilaram com rapidez o poder de julgar a constitucionalidade das leis e de garantir a inviolabilidade dos direitos individuais. Com senso de responsabilidade e com segurança. o Tribunal passou imediatamente a funcionar dentro de sua ampla missão de Corte Constitucional e de Curte de Cassação, utilizando os poderes que a Constituição não explicitava, mas que de seu texto se extraíam implicitamente, por um processo de construçào como fazia a Corte Suprima dos Estados Unidos.

Interessante observar que, além das suas tradicionais funções típicas, o novo sistema entregou à Justiça Federal a guarda da Constituição, das leis e dos direitos individuais, mesmo em face de atos emanados pelos demais Poderes da República. A mudança de enfoque é visível. O Poder Judiciário, ao menos a Justiça Federal, passa a exurcer competências de alto relevo, certamente complexas e sobrutudo delicadas.

Também merece destaque a vitaliciedade e inamovibilidade dos Juízes de Secção, cuja perda do cargo dependeria de sentença passada em julgado (art. $2^{\circ}$ do Decreto n. 848, de 1890) e a inamovibilidade dos juízes substitutos (art. 18 do Decreto $n$. 848, de 1890). Evidentemente, sem tais prerrogativas, a independência do magistrado poderia se prejudicar. ainda porque suas decisões poderiam afetar diretamente os interesses dos demais Poderes.

A Carta de 1891 constitucionalizou a Justiça Federal. ao prevê-la em seus arts. 55 e seguintes. Manteve-se. em síntese, as regras estabelecidas no Decreto n. 848. Apenas se acrescentou, dentre as competências do STF, a de processar e julgar os

14 "O Supremo Tribunal Federal ontem e hoje" in Anais do sı'minário: o Supremo Tribunal Federal na história da Repuiblica. editado pela AJUFE, Brasilia, 2002, p. 593. 
ministros de Estado, nos crimes comuns e nos de responsabilidade, quando não fossem de competência do Senado Federal (art. 59, I, "a" da CF//891).

$\mathrm{O}$ art. 55 desta Carta previu a criação de Tribunais Federais, não disciplinando, entretanto, sua competência. Determinou apenas que caberia ao Congresso deliberar sobre sua criação. Aqui lançou-se a semente do saudoso Tribunal Federal de Recurso e dos atuais cinco Tribunais Regionais Federais.

Em seguida, a Lei n. 221, de 20 de novembro de 1884 , complementou a organização da Justiça Federal, substituindo o juiz ad hoc pelo juiz suplente do substituto $\left(\right.$ art. $2^{\circ}$ ). À Primeira Instância foi adicionada a competência de processar e julgar as causas que versassem sobre: "marcas de fábrica, privilégios de invenção e propriedude litteraria" (art. 12) c, ainda, as causas fundadas na lesão de direitos individuais por atos ou decisões de autoridades administrativas da União (art. 13).

Novas competências foram conferidas ao STF. que passou a processar e julgar, originaria e privativamente, os seus membros, nos crimes comuns (art. 22, "a", I) e os Juizes Federais, seus substitutos e suplentes, nos crimes de responsabilidade (art. 22, "a", II), bem como as reclamações de antigüidade dos juízes federais (art. 22, "a" III); julgar, em última instância, os recursos de qualificação dos jurados federais, interpostos dos despachos dos juizes seccionais sobre reclamações de inclusão ou exclusão (art. 22, "b" I) e os recursos e apelações dos despachos e sentenças do juiz. seccional nos processos de responsabilidade dos procuradores da República, dos ajudantes e solicitadores; além de outras atribuições especificas (art. 22, "b" II).

O Decreto n. 3.084, de 05 de novembro de 1898, regulamentou a Lei $n$. 221// 894 e aprovou a Consolidação das Leis referentes à Justiça Federal, que passou a ser chamada de "Justiça da União" composta pelo Supremo Tribunal Federal, pelos juízes seccionais, Substitutos e Suplentes, além dos Tribunais do Júri Federal (art. $l^{\circ}$ ).

O STF passou a ser competente para o julgamento dos membros do Tribunal de Contas, nos crimes de responsabilidade (art. $9^{\circ}$ "f") e a indicação ao Presidente da República dos cidadãos aptos à magistratura federal (art. 11. "b"). A competência dos juízes seccionais passaram a conter o processo e julgamento: dos crimes de responsabilidade dos procuradores seccionais, adjuntos, ajudantes, solicitadores e uscrivães (art. 57, "k"); os crimes de falsificação de moeda ou títulos públicos, peculato e contrabando (art. 57, "I"); e as causas de natureza federal em matéria civil que eram da alçada do extinto Juízo da Fazenda Nacional (art. 58).

A Revolução de 1930, cujo resultado foi flagrantemente centralizador, não alterou, de início, a estrutura da Justiça Federal. Mas, como será ainda visto, esta circunstância não tardou a modificar-se. 
A Constituição de 1934 estabeleceu que o Supremo Tribunal Federal denominar-se-ia, desde então, Corte Suprema (art. 63), tendo incluído em sua competência o julgamento, em recurso ordinário, das causas, inclusive mandados de segurança, decididas por Juizes e Tribunais Federais (art. 76, "a”).

Os juizes federais passaram a ser nomeados pelo presidente da República, por meio de uma lista quíntupla elaborada pela Corte Suprema (art. 80, parágrafo único). Além das competências atribuídas nas leis anteriores, à Primeira Instância carreou-se o processo e julgamento dos mandados de segurança contra atos de autoridades federais e dos crimes praticados contra a ordem social, inclusive o de regresso ao Brasil de estrangeiro expulso (art. 81, "k" e "l").

Ocorreu significativa mudança nas regras de Direito Processual. Instituiu-se a unidade, em substituição ao pluralismo anterior ${ }^{15}$ (art. $5^{\circ}$, IX, "a"), sem, contudo, alterar o dualismo da Justiça. Assim, cada Estado-membro continuou mantendo o próprio sistema judiciário local.

Importa notar que esta Carta reverenciou as garantias da magistratura da vitaliciedade, inamovibilidade e irredutibilidade de vencimentos (art. 64).

\section{Centralização, autoritarismo e morte da Justiça Federal}

O arbítrio instaurado pela Revolução de 30 indica alteração radical de rumo. Em novembro de 1930, apenas um mês após a tomada do Poder por Getúlio Vargas, era dissolvido o Congresso Nacional, os legislativos estaduais e municipais. Todos os antigos governadores, salvo o eleito por Minas Gerais, foram demitidos, nomeando-se em seus lugares interventores federais.

O princípio federativo foi praticamente esquecido, com o visivel enfraquecimento dos Estados-membros. A centralização na pessoa da União extrema era manifesta, com sobreposição do Poder Executivo. ${ }^{10}$

Evidentemente, o Poder Judiciário, especificamente a Justiça Federal, acabou sendo atingida por atos autoritários. Cita-se, apenas a título ilustrativo, o Decreto n. 22.169, de 05 de dezembro de 1932, que extinguiu a $2^{\text {a }}$ Vara do Juízo Federal na Seção de São Paulo. Na mesma linha, o Decreto n. 22.170, da mesma data, aposentou o juiz federal da $1^{a}$ Vara da Seção de São Paulo, Washington Osório de Oliveira, com os vencimentos a que fizesse direito, de acordo com a legislação vigente. Seriam tais medidas disfarçadas punições em face da recente Revolução Constitucionalista ocorrida

\footnotetext{
15 Até então, cada Estado-membro editava seus respectivos Códigos processuais.

16 Para maior aprofundamento: BORIS. Fausto. História do Brasil. São Paulo: Editora Edusp. 1995. p. 319 e seguintes.
} 
em São Paulo? É curioso notar a proximidade de tais acontecimentos (a Revolução iniciou-se em 09 dc julho c a rendição de São Paulo foi assinada em outubro).

O golpe final veio com o Estado Novo, de inopino. Matou-se a Justiça Federal em pancada única. O art. 90 da Carta outorgada de 1937, de triste memória, não a elencou como um dos Órgãos do Poder Judiciário. Os juízes e funcionários da Justiça Federal, não-admitidos na nova organização judiciária e que gozavam da garantia da vitaliciedade, foram aposentados com todos os vencimentos, desde que contassem mais de 30 anos de serviço. Os demais. restaram em disponibilidade com vencimentos proporcionais ao tempo de serviço até eventual aproveitamento em cargos de vantagens equivalentes (art. 182 da Carta de 1937).

Por conseguinte, as causas propostas pela União ou contra ela deveriam ser aforadas em um dos Juizos da Capital do Estado em que for domiciliado o réu ou o autor (art. 108). E, das sentenças proferidas pelas Primeira Instância nas causas em que a União fosse interessada como autora ou ré, assistente ou oponente, haveria recurso diretamente para o Supremo Tribunal Federal (art. 109).

À evidência, a ditadura então estabelecida não precisava mais tolerar uma Justiça Federal que a qualquer momento poderia opor-lhe decisões obstativas, criando empecilhos despiciendos às "legítimas aspirações do povo brasileiro" 1 "

Quem ousaria resistir? O Poder era absoluto e intolerante com dissidentes. Não havia imprensa livre. Tanto é assim que algumas publicações da época que aplaudiram o evento.

O Diário Carioca, de 11 de novembro de 1937, assim se manifestava:

A carta de 1934, a despeito das melhores intenções que insp:raram os seus autores, não conseguiu conciliar os ideais da Revolução de 1930. Obra de políticos, por isso mesma cheia de defeitos e contra-sensos. ela sacrificou muitas das promessas feitas à Nação pelos revolucionários yue tiveram como chefe civil o Sr. Getúlio Vargas. Dando ao Brasil outra Constituição o Sr. Getúlio Vargas se reinveste na qualidade de chefe da Revolução de 30 e retoma o ritmo interrompido de sua grande obra. É, pois. na autoridade moral do presidente da República, nos anscios da Nação que quer viver $\mathrm{c}$ prosperar sem os tropeços de fornalismos irrealistas

17 Conforme Jorge Caldeira: "O esforço de centralização iniciado em 1930 completou-se sete anos depois. Com a ditadura vieram a censura à imprensa, o culto á personalidade de Cietúlio. o controle dos sindicatos operários, as prisōes arbitrárias. Uma nova constituição outorgada às pressas e modificada apenas pelo presidente era a única ordem legal vigente, na qual o governo podia muito e os cidadãos quase nada. E. como cm toda ditadura. oferecia-se um grande plano como lenitivo para as dores do momento: a industrialização rápida do pais" (Viagem pelu hisı́ria do Brasil. 2. ed. São Paulo: Editora Companhia das Lulras. 1997. p. 280). 
e no sangue dos brasileiros imolados por um Brasil maior, que vamos encontrar a legitimação da nossa nova Carta Politica.

Segundo "A Nação" na mesma data: "Brasileiros! A Defesa Social Brasileira é um novo Arraial do Bom Jesus erigido como baluarte do Brasil contra a invasão vermelha. Nenhum patriota poderá ficar alheio ao seu grande apelo. Alistai-vos!"

\section{Renascimento em Segunda Instância}

A Idade das Trevas perdurou até o final da Segunda Grande Guerra. Getúlio Vargas deixa o poder. Os ares de liberdade invadem o país. A democracia é restaurada. $\mathrm{O}$ princípio federativo começa a respirar de novo.

Nessa época, o constituinte de 1946, certamente em homenagem aos princípios republicano e federativo, sabedor da importância de o País contar com um Poder Judiciário independente e eficaz para as causas que envolvessem a União, reinstituiu a Justiça Federal em Sigunda Instância, ao prever, em seu art. 94, Il, o saudoso Tribunal Federal de Recursos, composto por nove juízes (art. 103). ${ }^{18}$

Em competência originária, ao TFR era incumbido processar e julgar: a) as ações rescisórias de seus acórdãos; b) os mandados de segurança, quando a autoridade coatora fosse ministro de Estado, o próprio Tribunal ou o seu presidente; e, em grau de recurso: a) as causas decididas em Primeira Instância, quando a União fosse interessada como autora, ré, assistente ou opoente, exceto as de falência; ou quando se tratasse de crimes praticados $\mathrm{em}$ detrimento de bens, serviços ou interesses da União, ressalvada a competência da Justiça Eleitoral e a da Justiça Militar; b) as decisões de juízes locais, denegatórias de habeas corpus e as proferidas em mandados de segurança, se federal a autoridade apontada como coatora (art. 104).

O Supremo Tribunal Federal deixa de atuar como órgão revisor ordinário das sentenças prolatadas em Primeira Instância, cujas causas comportassem interesse da União. Tal função, com efeito, passou ao Tribunal Federal de Recursos (art. 104, II, "a").

A possibilidade de criação de outros Tribunais Federais, por meio de lei ordinária. mediante proposta do próprio TFR, também foi estabelecida nesta Carta (CR/46, art. 105). Todavia, tal evento não chegou a ocorrer até a Carta de 1988.

$\mathrm{E}$ assim os anos foram se passando. O País começa mudar seu perfil com a migração da população rural aos grandes centros urbanos; a indústria toma fôlego; o automóvul invade as ruas; as cidades e suas mazelas crescem, até que se foi percebendo a

18 A Justiça Comum dos Estados continuou processando e julgando, em Primeira Instância. as causas de interesse da União. 
inarredável necessidade da Justiça Federal ser estruturada também em Primeira Instância, tendo em vista suas peculiaridades naturais, as partes envolvidas, os tipos de demandas, etc.

Ademais, o sustento das antigas Varas de Fazenda Nacional pelos diversos Estados significava gasto elevado e em dissonância com as finalidades essenciais da Justiça Comum.

\section{Renascimento em Primeira Instância}

Em 31 de março de 1964 inicia-se o Regime Militar. O Ato Institucional n. 2, de 27 de outubro de 1965, recriou a Justiça Federal de Primeira Instância (art. $6^{\circ}$, II). Infelizmente, face às delicadas circunstâncias políticas de então, não é absurdo cogitar tenha seu renascimento vórtice mais ligado às necessidades de ordem administrativa e arrecadatória do que aos ideais republicanos inspiradores do Decreto n. 848 de 1890.

Os juízes federais eram nomeados pelo presidente da República a partir de lista quíntupla elaborada pelo Supremo Tribunal Federal ( $a r t .6^{\circ}$ do AI n. 2, que deu nova redação ao art. 105 da CF de 1946). A eles competia processar: a) as causas em que a União ou entidade autárquica federal fosse interessada como autora, ré, assistente ou opoente, exceto as de falência e acidentes de trabalho; b) as causas entre Estados estrangeiros e pessoa domiciliada no Brasil: c) as causas fundadas em tratado ou em contrato da União com listado estrangeiro ou com organismo internacional; d) as questões de direito marítimo e de navegação. inclusive a aérea; e) os crimes políticos e os praticados em detrimento de bens, serviços ou interesse da União ou de suas entidades autárquicas, ressalvada a competência da Justiça Militar e da Justiça Eleitoral; f) os crimes que constituíam objeto de tratado ou de convenção internacional e os praticados a bordo de navios ou aeronaves, ressalvada a competência da Justiça Militar; g) os crimes contra a organização do trabalho e o exercício do direito de greve; h) os habeas corpus em matéria criminal de sua competência ou quando a coação proviesse de autoridade federal não subordinada a órgão superior da Justiça da União: i) os mandados de segurança contra ato de autoridade federal, excetuados, os casos do art. 101, I, i, e do art. 104, I. b ( $\$ 3^{\circ}$ do art. $6^{\circ}$ do AJ n. 2).

Para cada Fistado e o Distrito Federal previu-se a criação de uma Seção Judiciária ( $\left(1^{\circ}\right.$ do art. 105 da $C F / 46$, com a redação dada pelo Al n. 2). A composição do Tribunal Federal de Recursos foi ampliada para treze juízes, dos quais oito seriam magistrados e cinco advogados e membros do Ministério Público, escolhidos c nomeados pelo presidente da República, com a anuência do Senado Federal (art. 103 da C.F/46, com a redação dada pulo AI n. 2). 
Na ocasião, a independência da Magistratura (não apenas a federal) restou seriamente prejudicada, pois o AI n. 2 estabeleceu a suspensão das garantias de vitaliciedade e inamovibilidade dos juizes. A partir desse ato, os magistrados poderiam ser demitidos, removidos, postos em disponibilidade ou aposentados, se demonstrassem incompatibilidade com os objetivos da Revolução (art. 14, parágrafo único). ${ }^{19}$

Foi a Lei n. 5.010, de 30 de maio de 1966, que organizou a Justiça Federal de Primeira Instância.

Em cada Estado, Território e no Distrito Federal foi instalada uma Seção Judiciária (arts. $2^{\circ}$ e $3^{\circ}$ ). Criou-se o Conselho da Justiça Federal, composto pelo presidente, vice-presidente e 3 (três) ministros do Tribunal Federal de Recursos. com competência para tratar de questões disciplinares dos juízes e funcionários e de outros assuntos administrativos da Justiça Federal de Primeira Instância (arts. $4^{\circ}$ e $6^{\circ}$ ). As Varas Federais só deveriam existir no interior do Estado quando houvesse mais de uma Vara na Capital (art. 12). A Justiça Ĺstadual foi delegada competência para julgamento dos executivos fiscais, das vistorias, das justificações e das matérias de nature za previdenciária nas Comarcas do interior sem Vara Federal (art. 15).

Naquele tempo, interessante notar que o ingresso no cargo de juiz fideral não se operava por concurso público, mas sim por nomeação pelo Presidente da República, mediante lista quíntupla elaborada pelo Supremo Tribunal Federal (art. 19 da Lei n. 5.010).

Todavia, o art. 20 da Lei n. 5.010, demonstrando já naquele época a preocupação do legislador com a eficiência administrativa e jurisdicional, por meio da seleção dos melhores candidatos, determinou que os cargos de Juiz Federal Substituto fossem providos por meio de concurso público.

A Carta de 1967 conferiu status constitucional à Justiça Federal em ambas Instâncias, conforme previsto pelo art. 107, II. As garantias da vitaliciedade, inamovibilidade e irredutibilidade de vencimentos foram elencadas no seu art. 108.

Inovando, a Carta de 1967, em scu art. 118, determinou que os Juízes Federais também ingressassem na carreira mediante concurso público de provas e títulos, devendo possuir idade mínima de 30 (trinta) anos.

19 Curioso notar que essas indispensáveis garantias entraram em franco movimento pendular, o que evidencia a instabilidade política e social vivida à época. Com efeito, de inicio, as garantias retornaram à vigência na Carta de 1967 (art. 108), promulgada em 24 de janeiro. Menos de 2 (dois) anos depois, entretanto, foram mais uma vez abafadas, por força do art. $6^{\circ}$ do Ato Institucional n. 5 . de 13 de dezembro de 1968. Ao depois, em 17 de outubro de 1969, com a Emenda n. 1, nos moldes da nova redação dada ao an. 113 da Carta de 1967, reviveram. 
Todavia, as garantias da magistratura são fortemente abaladas em 13 de dezembro de 1968. quando da edição do Ato Institucional n. 05, ocasião em que foram sumariamente suspensas, inclusive podendo o presidente da República demitir, aposentar ou pôr em disponibilidade quaisquer titulares das mesmas (art. $6^{\circ}, \S 1^{\circ}$ ), restando afastada a apreciação judicial de todos os atos praticados em decorrência daquele Ato Institucional (art. 11).

A situação perdura até a Fimenda n. 01, de 17 de outubro de 1969, que altera sobremaneira a Carta de 1967, quando, finalmente, as garantias retornam ao vigor, conforme o disposto no art. 113 (redação dada pela EC n. 01).

Mais adiante, a Emenda n. 07, de 13 de abril de 1977 ampliou a composição do Tribunal Federal de Recursos que passou a contar com 27 (vinte e sete) julgadores. $O$ preenchimento de quinze desses cargos passaria a dar-se pelo critério exclusivo de promoção de juízes léderais, yuatro dentre membros do Ministério Público Federal, quatro dentre advogados e quatro dentre magistrados ou membros do Ministério Público dos Estados e do Distrito Federal

Finalmente, chega-se a Constituição de 1988, cuja principal inovação foi a extinção do Tribunal Federal de Recursos c, em seu lugar, a criação de cinco Tribunais Regionais Federais, ${ }^{20}$ possibilitando ao jurisdicionado uma maior proximidade com a Justiça Federal de Segunda Instância.

Segundo o art. 108 da Constituição de 1988, os Tribunais Regionais Federais possuem competência originária e recursal. Sob a primeira, a estas Cortes cabe processar e julgar: a) os juízes federais da área de sua jurisdição, incluídos os da Justiça Militar e da Justiça do Trabalho, nos crimes comuns e de responsabilidade, e os membros do Ministério Público da União, ressalvada a competência da Justiça Eleitoral; b) as revisões criminais e as ações rescisórias de julgados seus ou dos juizes federais da respectiva Região; c) os mandados de segurança e os habeas-data contra ato do próprio Tribunal ou de juiz federal; d) os habeas-corpus, quando a autoridade coatora for juiz. federal; e) os conflitos de competência entre juízes federais vinculados ao Tribunal.

Em grau de recurso, os TRF's são competentes para decidir as causas decididas pelos juízes federais e pelos juízes estaduais no exercício da competência federal da área de sua jurisdição.

20 Assim: a) TRF da $I^{2}$ Região, com sede um Brasilia-DF e jurisdição sobre os Estados do Acre. Amapá Amazonas, Bahia. Distrito Federal, Goiás, Maranhão. Mato Grosso, Minas Gerais, Pará, Piaui, Rondônia, Roraima c Tocantins; b) TRF da 2" Região, com sede no Rio de Janeiro e jurisdição sobre os Estados do Espírito Santo e Rio de Janeiro: c) TRF da $3^{x}$ Região, com sede em São Paulo e jurisdição sobre os Estados do Mato Grosso do Sul e São Paulo: d) TRF da $4^{a}$ Região, com sede em Porto Alegre e jurisdição sobre os Estados do Paraná, Rio Grande do Sul e Santa Catarina; e) TRF da $5^{2}$ Região, com sede em Recife e jurisdição sobre os Estados de Alagoas, Ceará, Paraiba, Pemambuco, Rio Grande do None e Sergipe. 
A competência da Primeira Instância restou estipulada no art. 109 da CF, sendo os juízes federais competes para processar e julgar: a) as causas em que a União. entidade autárquica ou empresa pública federal forem interessadas na condição de autoras, rés, assistentes ou oponentes, exceto as de falência, as de acidentes de trabalho e as sujeitas à Justiça t:leitoral e à Justiça do Trabalho; b) as causas entre Estado estrangeiro ou organismo internacional e Município ou pessoa domiciliada ou residente no País: c) as causas fundadas em tratado ou contrato da (Inião com Estado estrangeiro ou organismo internacional; d) os crimes políticos e as infrações penais praticadas em detrimento de buns, serviços ou interesse da União ou de suas entidades autárquicas ou empresas públicas, excluidas as contravenções e ressalvada a competência da Justiça Militar e da Justiça Eleitoral; e) os crimes previstos em tratado ou convenção internacional, quando, iniciada a execução no Pais, o resultado tenha ou devesse ter ocorrido no estrangeiro, ou reciprocamente; f) as causas relativas a direitos humanos a que se refere o $\S 5^{\circ}$ do art. 108; g) os crimes contra a organização do trabalho e, nos casos determinados por lei, contra o sistema financeiro e a ordem econômico-financeira: h) os habeas-corpus, em matéria criminal de sua competência ou quando o constrangimento provier de autoridade cujos atos não estejam diretamente sujeitos a outra jurisdição; i) os mandados de segurança e os habeas-data contra ato de autoridade federal, excetuados os casos de competência dos Trihunais Federais; j) os crimes cometidos a bordo de navios ou acronaves, ressalvada a competência da Justiça Militar; 1) os crimes de ingresso ou permanência irregular de estrangeiro, a execução de carta rogatória, após o exequatur, e de sentença estrangeira, após a homologação, as causas referentes à nacionalidade, inclusive a respectiva opção, e à naturalização e m) a disputa sobre direitos indígenas.

\section{O crescimento da Justiça Federal na Terceira Região ${ }^{21}$}

A instalação do Tribunal Regional Fèderal da $3^{\text {a }}$ Região ocorreu em 30 de março de 1989, nos moldes da Lei n. 7.727, de 09 de janeiro daquele ano.

O início da Corte. como não poderia deixar de ser, foi impregnado por adversidades que implicaram, não raras vezes, em esforço colossal de todos: juizes. procuradores, advogados, funcionários e o público em geral. Sem o desprendimento incondicional da maioria, a situação certamente se tornaria insuportável.

Os milhares de feitos não tardaram a chegar, na maioria provenientes do Tribunal Regional Federal de Recursos. Não havia qualquer minuto a ser pcrdido:

2! Aqui é conferido enfoque especial à $3^{3}$ Região, pois c o local do excrcicio da judicatura do autur. A 3 " Região da Justiça Federal é composta pelos Estados de São Paulo e Mato Grosso do Sul. 
trabalho hercúleo e incessante aliado à precariedade das condições materiais iniciais. E assim se começou, fazendo-se o que era possível, não se poupando esforços na superação dos obstáculos.

A Corte, inicialmente, foi composta por 18 (dezoito) julgadores. ${ }^{22}$ A pletora de feitos, em verdade, nunca deu trégua, sempre teimando em crescer, crescer, crescer....

O incessante crescimento já implicou em 2 (duas) ampliações da Corte. Assim, com a Lei n. 8.418, de 27 de abril de 1992 (art. $1^{\circ}$ ), o número de juízes se elevou para 27 (vinte e sete) e, pela Lei n. 9.968, de 10 de maio de 2000 (art. $1^{\circ}$ ), os componentes do Tribunal passaram a ser 43 (quarenta e três). Serão bastante? Atí quando? O assoberbo já se faz sentir novamente, provocando congestionamento nos trabalhos, ainda que se desenvolvam esforços contínuos no sentido de dar vazão aos casos pendentes.

$O$ fenômeno revelou-se semelhante na Primeira Instância, com impressionante aumento do número dos feitos ajuizados, verdadeiro agigantamento. conforme a tabela abaixo:

\begin{tabular}{|c|c|c|}
\hline ANO & FEITOS EM DEZEMBRO & JULGAMENTOS NO ANO \\
\hline 1989 & 214.087 & 27.896 \\
\hline 1990 & 225.329 & 44.829 \\
\hline 1991 & 461.086 & 85.769 \\
\hline 1992 & 458.367 & 177.094 \\
\hline 1993 & 399.608 & 112.982 \\
\hline 1994 & 357.649 & 113.448 \\
\hline 1995 & 414.290 & 74.925 \\
\hline 1996 & 479.441 & 80.579 \\
\hline 1997 & 651.338 & 94.306 \\
\hline 1998 & 724.859 & 11.898 \\
\hline 1999 & 819.683 & 137.692 \\
\hline 2000 & 955.485 & 151.073 \\
\hline 2001 & 1.026 .176 & 135.711 \\
\hline 2002 & 1.167 .117 & 127.696 \\
\hline 2003 & 1.317 .150 & 149.621 \\
\hline 2004 & 1.521 .838 & 169.793 \\
\hline 2005 & $1.580 .861($ até setembro) & 79.890 (até setembro) \\
\hline
\end{tabular}

Art. $2^{\circ}$ da Lei n. $7.727 / 89$. 
O número de juízes, como seria esperado, também se elevou, mas em proporção menor do que os feitos aforados. Assim í que, em dezembro de 1989, havia apenas 34 magistrados federais, sendo 225 em setembro de 2005, entre juízes titulares e substitutos. Em conclusão, em dezembro de 1989 existiam, em média, 6.296,67 para cada julgador, tendo subido para 7.026,04 em setembro de 2005.

Ainda que o aumento da média não seja tão expressivo, não se pode negar que ter sob responsabilidade de processar e julgar em média 7 mil processos não é tarefa simples, considerando que muitos feitos são extremamente complexos e de elevado interesse para a coletividade, v.g., ações civis públicas, ações populares, etc. Infelizmente, algum atraso acaba sendo inevitável.

9. A Justiça Federal na defesa dos cidadãos

É oportuno recordar as históricas posições adotadas pela Justiça Federal, não apenas na $3^{\text {a }}$ Região mas em todo País, em momentos cruciais do passado recente, ressaltando-se os julgamentos acerca do Plano Collor, a partir de 1990, no sentido de determinar às autoridades a imediata liberação de importâncias bloqueadas ilegitimamente pelo Governo da época, nos moldes preceituados pela Medida Provisória n. 168/90.

O Plano havia sido alardeado aos quatro ventos, pela imprensa falada e televisiva, como verdadeiro "salvador da pátria", única medida capaz de controlar a inflação galopante de então. Seu fracasso, segundo usualmente se defendia, implicaria em incontrolável convulsão social e muitos outros males de conseqüências nefandas e imprevisiveis.

Em verdade, os juízes federais não se deixaram intimidar por toda aquela verdadeira propaganda política, ao contrário, sempre se posicionaram de modo seguro, sem alarde, de acordo com as suas consciências e em respeito à Constituição.

Corajosamente, tanto a Primeira quanto a Segunda Instância da Justiça Federal da $3^{a}$ Região, em milhares de decisões, afastaram as inconstitucionais medidas restritivas adotadas pelo Governo naquele instante, devolvendo aos milhares de demandantes não apenas sua propriedade, mas principalmente a certeza de que se fazia Justiça.

E assim tem ocorrido ao longo dos anos, apenas recordando a resposta positiva dada face às dezenas de milhares de ações de cobrança das diferenças do FGTS, em parte também conseqüência do Plano de 1990, sempre de forma altiva, tendo como norte seguro, além da Carta Magna, os princípios da ética e da equidade. 
A constante instalação de Varas Iederais no interior dos Estados, fenômeno conhecido como "interiorização" com certeza. beneficia os mais carentes que sequer poderiam imaginar em arcar com os custos do aforamento de uma demanda na Capital. ou mesmo em local diverso do município onde residem. Dá-se vazão, portanto, à nefasta "litigiosidade contida" Rui Barbosa já afirmava: ${ }^{23}$

Antes, com os mais miseráveis í que a justiça deve ser mais atenta, e redobrar de escrúpulo; porque são os mais mau defendidos, os que suscitam menos interêssci. e os contra cujo direito conspiram a inferioridade na condição com a mingua nos recursos.

Além do mais, nâo se pode esquecer, segundo bem expressou o Ministro Carlos Velloso" do STF que: "De outro lado, como consectário de sua própria natureza, o órgão estatal que a exercita, o Poder Judiciário, é o guardião maior dos direilos, a garantia das garantias constitucionais"

Em verdade. chega ser intuitivo concluir que sem o Judiciário materialmente acessível ao pobre, quem lhe garantirá as garantias constitucionais? Perpetuam-se as injustiças, os abusos, as nulidades, os crimes.

Nos últimos anos vários Municipios passaram a sediar Varas Federais na $3^{\mathrm{a}}$ Região. Em dezembro de 1989 havia 30 Varas Federais. Em janeiro de 2006 o número de Varas instaladas passa a ser de 140, além de 17 Juizados T:speciais Federais Cíveis. ${ }^{25}$

Us Juizados Especiais Federais Cíveis, com destaque para o de São Paulo e Mato Grosso do Sul, muito se aproximam de uma realidade de acesso a um Judiciário mais seguro e célere. Desconhece-se experiência anterior bem sucedida na tramitação de feitos em grande número sob ambiente totalmente virtual, isto é, sem a utilização de papel para documentar os autos.

Esta é. sem dúvida. uma realidade inarredável, que vem propiciando aos pustulantes de "pequenas causas" em sua maioria desprotegidos economicamente, prestação jurisdicional segura e inclusive mais rápida do que aquıla normalmente obtida nas Varas comuns, principalmente porque, além da tramitação, a execução do julgado é quase que imediata, em face da dispensa de precatórios em hipóteses tais (CF, art. 100). As tabelas abaixo ilustram a atuação dos Juizados:

Oração aos moços. Rio de Janeiro: Gráfica Olímpica Editora - Luis Franco, 1951. p. 64.

Temas de direito público. $1^{a}$ ed., $2^{a}$ tir. Belo Horizonte: Livraria Del Rey Editora, 1997. p. 2 ?.

Regulados pela Lei n. 10.259/2001. 
JUIZADO ESPECIAL FEDERAL EM SÃO PAULO

\begin{tabular}{|c|c|c|}
\hline ANO & FEITOS EM DEZEMBRO & JULGAMENTOS NO ANO \\
\hline 2002 & 13.901 & 7.015 \\
\hline 2003 & 127.831 & 72.138 \\
\hline 2004 & 782.402 & 466.759 \\
\hline 2005 & 998.643 (outubro) & 310.755 (outubro) \\
\hline
\end{tabular}

JUIZADO ESPECIAL PREVIDENCIÁRIO EM MATO GROSSO DO SUL

\begin{tabular}{|c|c|c|}
\hline ANO & FEITOS EM DEZEMBRO & JULGAMENTOS NO ANO \\
\hline 2002 & 1.271 & 375 \\
\hline 2003 & 4.465 & 2.660 \\
\hline 2004 & 10.504 & 3.415 \\
\hline 2005 & 9.100 (outubro) & 5.704 (outubro) \\
\hline
\end{tabular}

Os números relacionados nas tabelas deste texto indicam que o acesso ao Judiciário na $3^{a}$ Região caminha, cada vez mais e na medida do possível, no sentido da concretude, revelando também nítido crescimento da expectativa que a sociedade vem depositando na Justiça Féderal, o que a engrandece como instituição sólida, mas também aumenta sua responsabilidade de responder a tais anseios sociais.

A qualidade do serviço judiciário, jamais poderia ter sido melhorada sem investimento na área de informática, notadamente a partir do final dos anos noventa. Com efeito, o computador marca, ou mesmo impõe, seu nem sempre amistoso convívio em absolutamente todos os sutores da Justiça Federal da $3^{\text {a }}$ Região, encontrando-se os principais sistemas interligados por rede avançada. Passou-se a viver on-line, o tempo todo.

Aliás, é fato que muitas comunicações oficiais interna corporis já são realizadas via e-mail, economizando-se escasso tempo e dispendioso papel.

O sites do Tribunal e da Primeira Instância permitem fácil acesso do público a inúmeras informações de relevo, notadamente o acompanhamento processual à distância, cujos benefícios são indiscutíveis.

Os avanços tecnológicos vivenciados pela informática na última década indicam ser este caminho sem volta. Certamente algum dia, espera-se não tão-distante, todo e qualquer processo judicial na $3^{\mathrm{a}}$ Região possua trâmite integralmente virtual. 
incluindo-se as intimações e demais atos externos, tudo levado a efeito sob apurado nível de segurança e confiança.

Indiscutivelmente, a informática sozinha não faz milagre. Seria imperdoável não-reverenciar o empenho desmedido dos juízes e funcionários que atuam diuturnamente. não se esquecendo, com razão, da colaboração e compreensão sempre aplaudida dos demais, quais sejam, procuradores da República, procuradores das autarquias e empresas públicas, defensores públicos, advogados e estagiários.

Novas perspectivas sempre se avizinham, ressaltando que a Emenda $n$. 45/2004, ao inserir o $\$ 5^{\circ}$ no art. 109 da CF, previu que:

Nas hipóteses de grave violação de direitos humanos, o Procurador-Geral da República, com al finalidade de assegurar o cumprimento de obrigações decorrentes de tratados internacionais de direitos humanos ${ }^{26}$ dos quais o Brasil seja parte, poderá suscitar, perante o Superior Tribunal de Justiça. em qualquer fase do inquérito ou processo, incidente de deslocamento de competência para a Justiça Federal.

Trata-se, sem dúvida, de uma nova e importantíssima missão conferida à Justiça Federal, ligada diretamente à garantia da dignidade da pessoa humana, um dos fundamentos da República brasiieira (CF, art. $1^{\mathrm{o}}$ III).

A missão aqui certamente se fará árdua, principalmente se considerada as precárias e desiguais condições econômico-sociais e políticas do Brasil, seja nos aglomerados urbanos, seja nos rincões interioranos. Haverá correspondência ao anseio social? Espera-se que sim, todavia, até o presente momento não se tem noticia que o Superior Tribunal de Justiça tenha determinado o deslocamento da competência.

Completou-se a obra? Claro que não, quiçá suas bases.

À evidência, muito ainda deve ser feito na melhoria da prestação jurisdicional. Vários gargalos que atrasam os feitos ainda persistem. O planejamento incessante se impõe. Entretanto, não se trata apenas de uma questão de vontade dos juizes e funcionários, já que constantes limitações orçamentárias, muitas vezes, impedem o avanço desejado.

Finalizando, sob o acatamento de qualquer crítica construtiva (sempre bem vinda, aliás), não se pode negar que a atuação Justiça Federal, via de regra sob exceções pontuais, a coloca como órgão de relevo no equilíbrio do edifício republicano-federativo

26 E் de se conferir o estudo realizado por Enrique Ricardo Lewandowski: "A proteção dos direitos humanos no mercosul". "A protę̧ão dos dircitos humanos no mercosul" In: DIREITOS humanos globalização eronómica e integração regional. São Paulo: Ed. Max Limonad, s.d. p. 255 e seg. 
no Brasil; cada ve $L$ mais promotora e garantidora dos princípios republicanos, da cidadania e dignidade da pessoa humana. sempre com mira nos preceitos constitucionais, cuja observância efetiva é essencial à construção de um verdadeiro Estado Democrático de Direito.

São Paulo, dezembro de 2005.

\section{Referências}

ANDRADE, Paulo Bonavides Paes de. História constitucional do Brasil. 3. ed. Rio de Janeiro: Editora Paz e Terra, 1991.

BARbosa, RUI. Comentários à Constituição Federal brasileira. São Paulo: Editora Saraiva, 1933. v. 4.

. Oração aos moços. Rio de Janeiro: Gráfica Olímpica Editora - Luis Franco. 1951.

BASTOS, Celso Ribeiro. Curso de aireito constitucional. 19. ed. Sào Paulo: Editora Saraiva, 1998.

BORIS, Fausto. História do Brasil. São Paulo: Editora Edusp, 1995.

CALDEIRA, Jorge. Viagem pela história do Brasil. 2 ed. São Paulo: Editora Companhia das Letras, 1997.

SAI.LES, M. Ferraz de Campos. Exposiçâo de motivos ao decreto n. 848, de 1890.

DAL.LARI, Dalmo de Abreu. Elementos de teoria geral do estado. 19. ed. São Paulo: Fditora Saraiva. 1995.

. O estado federal. São Paulo: Editora Ática, 1986.

FERREIRA FII.HO, Manoel Gonçalves. Curso de direito constitucionul. 26. ed. São Paulo: Ėditora Saraiva, 1999.

JUCOVSKY, Vera Lúcia Rocha Souza. Justiça Federal nos paises que a adotam. Brasilia: Centro de Estudos Judiciários, 1997.

LEWANDOWSKI, Lnrique Ricardo. Direito comunitário e soberania - algumas reflexões. In: LEWANDOWSKI, Enrique Ricardo (Coord.). Direito comunitário e jurisdição supranacional. São Paulo: F.d. Juarc\% de Oliveira, 2000. p. 179 e seg. 
LEWANDOWSKI, Enrique Ricardo. A proteção dos direitos humanos no mercosul. In: PIOVESAN, Flávia (Coord.). Direitos humanos, globalização econômica e integração regional. São Paulo: Ed. Max I.imonad, s.d. p. 255 e seg.

REPERTÓRIO biográficu da Justiça Federal. s.ed., Brasília, editado pelo Centro de Estudus Judiciários, 2000.

RELATURIO estatistico de movimentação processual. s.ed., São Paulo, editado pelo TRF-3ả Região, 2003.

REZEK, J.F Direito internacional público: curso elementar. 2. ed. São Paulo: Editora Saraiva, 1991.

ROCHA, Carmén Lúcia Antunes da. "O Supremo Tribunal Federal como árbitro dos conflitos federativos" Anais do seminário o Supremo Trihunal Federal na história da república. editado pela AJUFE. Brasília. 2002.

SILVA. Evandro Lins. "O Supremo Tribunal Federal ontem e hoje" In: ANAIS do Seminário - O Supremo Tribunal Federal na história da republica. Brasilia: AJUFE, 2002.

SILVA, José Afonso da. Curso de direito constitucional positivo. 21. ed. São Paulo: Fditora Malheiros, 2002.

VELLOSO. Carlos Mário da Silva. Temas de dircito público. 1. ed., 2. tir. Belo Horizonte: Livraria Del Rey Editora, 1997.

SITES CONSULTADOS: www.cjf.gov.br www.fgv.org.br www.ibge.gov.br www.planalto.gov.br www.senado.gov.br www.stf.gov.br www.trf3.gov.br 